\title{
Variations in the Number and Drainage Levels of Retroaortic Left Renal Veins
}

\section{Retroaortik Sol Renal Venlerin Sayı ve Drenaj Düzeylerindeki Varyasyonlar}

\author{
SŞerife Leblebisatan', @Bozkurt Gülek' \\ University of Health Sciences, Adana City Training and Research Hospital, Department of Radiology, Adana, Turkey
}

\begin{abstract}
Aim: Circumaortic left renal vein (CLRV) and retroaortic left renal vein (RLRV) are the most common variations of the left renal vein and have a retroaortic course. We aimed to detect the anatomical variations of retroaortic left renal veins in terms of their number and entrance levels into the inferior vena cava (IVC).
\end{abstract}

Materials and Method: The computed tomographic (CT) images of 2804 patients who had undergone abdominal CT examinations in our hospital retrospectively were evaluated.

Results: CLRV variations were detected in 139 (4.96\%) patients while in another 132 (4.71\%) RLRV variations were detected. Double branches were present in 15 (10.8\%) patients in the RLRV group, and 3 patients (2.3\%) in the CLRV group. The most common drainage levels into the IVC for these variations were the L 3 vertebra level and the middle $1 / 3$ infrarenal IVC segment.

Conclusion: CLRV and RLRV may possess single or double retroaortic branches. The entrance levels into the IVC are various in these variations. Knowing these variations is important for surgical and interventional procedures.

Keywords: Renal veins, vena cava inferior, computed tomography
Öz

Amaç: Sirkumaortik sol renal ven (CLRV) ve retroaortik sol renal ven (RLRV), sol renal venin en yaygın varyasyonlarıdır ve retroaortik seyir gösterir. Retroaortik sol renal venlerin anatomik varyasyonlarını sayıları ve inferior vena cava'ya (IVC) giriş seviyeleri açısından tespit etmeyi amaçladık.

Gereç ve Yöntem: Hastanemizde retrospektif olarak abdominal BT incelemesi yapılan 2804 hastanın bilgisayarlı tomografik (BT) görüntüleri değerlendirildi.

Bulgular: CLRV varyasyonları 139 (\% 4.96) hastada tespit edilirken, 132 (\% 4.71) hastada RLRV varyasyonu tespit edildi. RLRV grubunda 15 (\% 10.8) hastada ve CLRV grubunda 3 hastada (\% 2.3) çift dal mevcuttu. Bu varyasyonlar için IVC'ye en yaygın drenaj seviyeleri, L3 vertebra seviyesi ve orta 1/3 infrarenal IVC segmentidir.

Sonuç: CLRV ve RLRV, tek veya çift retroaortik dallara sahip olabilir. IVC'ye giriş seviyeleri bu varyasyonlarda çeşitlidir. Bu varyasyonların bilinmesi, cerrahi ve girişimsel prosedürler için önemlidir.

Anahtar Kelimeler: Renal venler, vena cava inferior, bilgisayarlı tomografi. 


\section{INTRODUCTION}

The left renal vein (LRV) normally passes across the aorta from the frontal aspect, before entering the inferior vena cava (IVC). In the retroaortic left renal vein (RLRV) variation, the LRV passes from the posterior aspect of the aorta. In the circumaortic left renal vein (CLRV), there are two LRV branches, one passing in front of the aorta, and the other passing from behind. ${ }^{[1]}$ In CLRV and RLRV, there are further variations in both the number and the entrance levels into the IVC. In this study, we aimed to define variations of retroaortic left renal veins.

\section{MATERIAL AND METHOD}

For the study, abdominal computed tomography (CT) examinations of patients referred from various departments with various indications between May 2017 and June 2017 were evaluated retrospectively. Patients with left nephrectomy and renal agenesis, together with those patients whose left renal veins could not be evaluated well enough, were excluded from the study, and the remaining 2804 patients were taken into consideration. These patients were evaluated for the presence of a retroaortic LRV branch. We classified the retroaortic LRV drainage levels to the IVC according to the IVC segment and the lumbar vertebrae/disC level. The separation of the IVC into its segments was based on the right renal vein. The level that right renal vein reaches to the IVC is renal, above renal is suprarenal, below renal is infrarenal IVC until iliac bifurcation. We divided the infrarenal IVC into three according to its length: proximal, middle, and distal $1 / 3$.

The CT examinations of the patients were performed with two GE Optima 520 scanners. The scanners were products of the year 2014, and they were 16-detector multislice machines. 5-mm-thick slices were obtained for the examinations.

The categorical measurements were defined as numbers and percentages, and the numerical measurements as the mean and standard deviation values. Median and minimummaximum values were used if necessary, for numerical measurements. The Chi-Square Test was utilized in order to compare and evaluate the variation frequencies in accordance with gender distribution. The IBM SPSS Statistics Version 20.0 pocket program was utilized for all statistical analyses. The statistical significance level was 0.05 in all tests.

\section{RESULTS}

Of the 2804 patients, 1581 (56.4\%) were males, and 1223 $(43.6 \%)$ were females. The mean age of the patients was $45.4 \pm 20.2$ years $( \pm S D)$. The ages varied between $1-112$ years and the median was 46 .

A retroaortic branch of the LRV was present in 271 (9.7\%) patients. The ages of the patients with variations varied between 2 and 90 years and the mean \pm SD was $44.7 \pm 19.6$.
We found the prevalence rates $4.96 \%$ and $4.71 \%$ for CLRV and RLRV, respectively. In total, variations were detected in $8.6 \%$ of males and $11 \%$ of females. Our study demonstrated no gender differences in CLRV and RLRV variations. But other than that, we demonstrated that the LRV variations were more frequent in females when the total numbers were considered and the subgroups were not taken into consideration $(\mathrm{P}=0.030)$.

The retroaortic branch was singular in 136 (98\%) of the 139 CLRV patients, while $3(2 \%)$ patients had double retroaortic branches. In 117 (88.6\%) of the 132 RLRV patients, there was a single retroaortic LRV, whereas the remaining 15 (11.4\%) patients demonstrated double retroaortic LRVs.

The entrance levels of the retroaortic branches into the IVC in the LRV variations, in accordance with the lumbar vertebra /disc levels, are shown in Table 1, and according to the segments of the IVC are shown in Table 2.

Table 1. The entrance levels of the retroaortic branches into the IVC in the LRV variations, in accordance with the lumbar vertebra /disc levels.

\begin{tabular}{lccccc}
$\begin{array}{l}\text { Lumbar } \\
\text { vertebra and } \\
\text { intervertebral } \\
\text { disc levels }\end{array}$ & $\begin{array}{c}\text { CLRV with } \\
\text { single } \\
\text { retroaortic } \\
\text { branch no. } \\
\text { (\%) }\end{array}$ & $\begin{array}{c}\text { RLRV with } \\
\text { single } \\
\text { retroaortic } \\
\text { branch no. } \\
\text { (\%) }\end{array}$ & $\begin{array}{c}\text { CLRV with } \\
\text { double } \\
\text { branches } \\
\text { no. (\%) }\end{array}$ & $\begin{array}{c}\text { RLRV with } \\
\text { double } \\
\text { branches } \\
\text { no. (\%) }\end{array}$ & $\begin{array}{c}\text { Total } \\
\text { no. (\%) }\end{array}$ \\
\hline L1 & & $4(3)$ & & & $4(1.4)$ \\
L1-L2 & $2(1)$ & $5(4)$ & & & $7(2.4)$ \\
L2 & $52(38)$ & $34(29)$ & $1(17)$ & $6(20)$ & $93(32.2)$ \\
L2-L3 & $24(18)$ & $15(13)$ & $2(33)$ & $7(23)$ & $48(16.6)$ \\
L3 & $51(38)$ & $42(36)$ & $3(50)$ & $12(40)$ & $108(37.4)$ \\
L3-L4 & $3(2)$ & $7(6)$ & & $2(7)$ & $12(4.2)$ \\
L4 & $1(1)$ & $9(8)$ & & $3(10)$ & $13(4.5)$ \\
L4-L5 & $1(1)$ & $1(1)$ & & & $2(0.7)$ \\
L5 & & & & & \\
L5-S1 & $2(1)$ & & & & $2(0.7)$ \\
Total & $136(100)$ & $117(100)$ & $6(100)$ & $30(100)$ & $289(100)$ \\
\hline
\end{tabular}

CLRV: Circumaortic left renal vein, RLRV: Retroaortic left renal vein

Table 2. Segmental distribution of IVC entry levels of posterior branches in the left renal vein variations.

\begin{tabular}{lccccc} 
IVC segments & $\begin{array}{c}\text { CLRV with } \\
\text { single } \\
\text { retroaortic } \\
\text { branch no. } \\
\text { (\%) }\end{array}$ & $\begin{array}{c}\text { RLRV with } \\
\text { single } \\
\text { retroaortic } \\
\text { branch no. } \\
(\%)\end{array}$ & $\begin{array}{c}\text { CLRV with } \\
\text { double } \\
\text { branches } \\
\text { no. (\%) }\end{array}$ & $\begin{array}{c}\text { RLRV with } \\
\text { double } \\
\text { branches } \\
\text { no. (\%) }\end{array}$ & $\begin{array}{c}\text { Total } \\
\text { no. (\%) }\end{array}$ \\
\hline Suprarenal & $1(1)$ & & & & $1(0.3)$ \\
Renal & $4(3)$ & $10(8.6)$ & & $3(10)$ & $17(5.9)$ \\
Proximal IR & $46(34)$ & $33(28.2)$ & $3(50)$ & $8(26.7)$ & $90(31.1)$ \\
Middle IR & $70(51)$ & $49(41.8)$ & $3(50)$ & $13(43.3)$ & $135(46.7)$ \\
Distal IR & $12(9)$ & $16(13.7)$ & & $4(13.3)$ & $32(11.1)$ \\
Bifurcation & & $7(6)$ & & $1(3.3)$ & $8(2.8)$ \\
Left iliac vein & $3(2)$ & $1(1)$ & & $1(3.3)$ & $5(1.7)$ \\
Azygos vein & & $1(1)$ & & & $1(0.3)$ \\
Total & $136(100)$ & $117(100)$ & $6(100)$ & $30(100)$ & $289(100)$ \\
\hline
\end{tabular}

IVC: Inferior vena cava, CLRV: Circumaortic left renal vein, RLRV: Retroaortic left renal vein, IR: Infrarenal 
Regardless of the type of variation, the most frequent association that retroaortic branch of the LRV is drained into IVC was between L3 and middle 1/3 infrarenal IVC (22\%).

When we classified CLRV preaortic and retroaortic branches according to whether it is separate or connected at the renal hilus, the findings were as follows: in 96 patients with single retroaortic branch they were connected, in 40 patients with single retroaortic branch they were separate and in 3 patients with double retroaortic branches all of them were connected. Of the 139 cases, 99 cases have had connected branches (71.2\%) and 40 cases have had separate branches (28.9\%).

The diameters of the preaortic and retroaortic branches in the CLRV patients were compared, and thus the dominant branch was evaluated. Dominant anterior branch, equality and dominant retroaortic branch were determined $46 \%, 32 \%$, and $22 \%$, respectively.

\section{DISCUSSION}

Case reports are available on the number of left retroaortic renal veins and entrance levels to the inferior vena cava but, our study is the first study on this subject in the literature. Sabouri et al. have reported a double RLRV case..$^{[2]}$ In our study, we detected this variation to be $0.5 \%$ in the general population and $11.4 \%$ in the RLRV variation population (Figure 1). Sutariya ${ }^{[3]}$ reported a double RLRV in which the first one drains into IVC and the second one to the left iliac vein. In our study, one of the 15 double RLRV cases was of this type. We detected the prevalence of this variation as $0.04 \%$ in the general population. Pallangyo et al. ${ }^{[4]}$ have reported a sickle cell trait case, in which both of the preaortic renal veins drained into the IVC, while the posterior divisions drained into the azygos vein in the right and the hemiazygos vein in the left. In one case of our study, the RLRV drained into the azygos vein and had no connection with the IVC. Brancatelli et al. ${ }^{[5]}$ have reported an RLRV which entered into the left iliac vein. Karaman et al. ${ }^{[6]}$ have published an article reporting RLRV variations draining into the left iliac vein in 3 of the 1856 cases they had studied. In our study of 2804 patients, we detected 1 RLRV case with drainage into the left iliac vein. In our 3 CLRV cases, the retroaortic branch drained into the left iliac vein; while there was an IVC drainage at the bifurcation level in 7 RLRV cases and 1 double RLRV case. Nguyen ${ }^{[7]}$ has reported two cases with double left renal veins, both of which demonstrated a first renal vein at the normal location, and second renal veins at abnormal drainage levels. In the first case, this vein drained into the left common iliac vein after crossing the left common iliac artery posteriorly, while in the second case the vessel drained into the distal IVC after crossing the aorta posteriorly. In our study, we categorized these and similar cases as CLRV variations, because of the fact that one of the renal veins crossed the aorta anteriorly, while the other crossed the aorta or left main iliac artery posteriorly. Matsunaga et al..$^{[8]}$ have reported a CLRV case in which the retroaortic branch followed an oblique course and drained into the IVC at a more caudally located level compared to that of the preaortic branch. The CLRV variation has been defined as a left renal vein complex in which two branches, one preaortic and the other retroaortic, cross the aorta circumferentially and thus form a venous collar. ${ }^{[9]}$ We saw in our study that these two branches are never at the same level, and the preaortic branch is always located more cranially while the retroaortic one is always located more caudally.

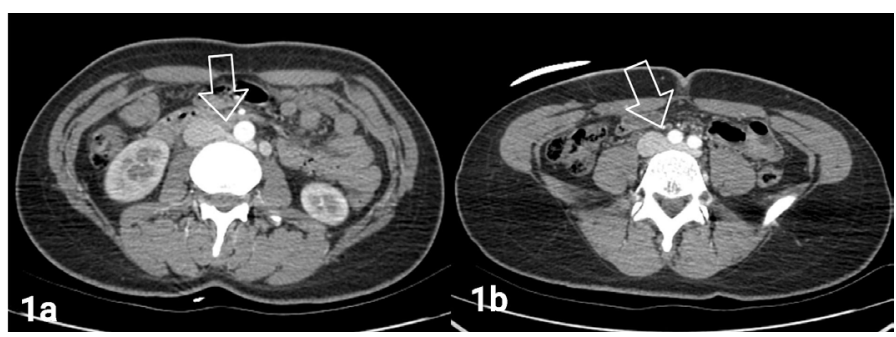

Figure 1. Contrast-enhanced axial upper abdominal CT scans in a 27-yearold female patient with a double RLRV variation. The more cranially located branch drains into the middle $1 / 3$ infrarenal IVC segment, which is approximately the L2 - L3 disc level (1a). The more caudally located branch, on the other hand, drains into the left iliac vein, which is approximately at the L4 vertebra level (1 b).

The drainage levels of the renal veins into the inferior vena cava in the adult population are reported to be at the T12 - L2 levels. ${ }^{[10]}$ We found out that 185 of the 289 retroaortic veins, drained into the IVC below the L2 level (64\%). We saw in our study that the retroaortic left renal veins drained into the IVC mostly at the L3 level. The IVC level which the renal veins drain into is called the renal IVC segment. But in our study we found out that the retroaortic left renal veins mostly drained into the IVC at the infrarenal level, the middle $1 / 3$ infrarenal segment being the most frequent one. This means that the retroaortic left renal veins travel on a more angular and oblique course and drain into the IVC more caudally. The reason for this formation might be the compression of the vein between the aorta and the lumbar vertebrae.

When the preaortic and retroaortic branches of the CLRV cases were compared according to their diameters, it was found that mostly the preaortic branch was wider than the retroaortic branch. The main branch is the anterior branch. Again, this may be due to the compression of the retroaortic branch between the aorta and the vertebrae, too.

The limitation of our study is, the patients who have been performed abdominal CT with different indications, will not reflect the general population.

\section{CONCLUSION}

Left renal vein variations are not clinically evident, but they are the most commonly encountered renal vein variations. These variations may have further variations in the number of branches and entrance levels into the IVC. Knowing these variations is extremely important for safe surgical and interventional procedures. 


\section{ETHICAL DECLARATIONS}

Ethics Committee Approval: Ethical approval was obtained from the local Ethical Committee (meeting number: 66 Cukurova University Medical School (07.07.2017)).

Informed Consent: Because the study was designed retrospectively, no written informed consent form was obtained from patients.

Referee Evaluation Process: Externally peer-reviewed.

Conflict of Interest Statement: The author(s) declared no potential conflicts of interest with respect to the research, authorship, and/or publication of this article.

Financial Disclosure: The authors declared that this study has received no financial support.

Author Contributions: All of the authors declare that they have all participated in the design, execution, and analysis of the paper, and that they have approved the final version.

\section{REFERENCES}

1. Dilli A, Ayaz UY, Kaplanoğlu H, Saltas H, Hekimoglu B. Evaluation of the left renal vein variations and inferior vena cava variations by means of helical computed tomography. Clin Imaging 2013;37(3):530-5.

2. Sabouri S, Hosseini A, Shivaei SS. Retro-aortic inverted left renal vein: a rare anomaly found in a renal donor. Iran J Radiol 2015;22;12(2).

3. Sutariya HC. Dual Retro-Aortic Left Renal Vein with Drainage into Left Common lliac Vein: Rare Anomaly of Left Renal Vein. Int J Organ Transplant Med 2016;7(2):99-101.

4. Pallangyo $P$, Lyimo $F$, Nicholaus $P$, Masatu S, Janabi M. Bilateral anomalous drainage of the posterior divisions of renal veins into the azygos system in a 20-year-old woman: a case report. J Med Case Rep 2016;10:344.

5. Brancatelli G, Galia M, Finazzo M, et al. Retroaortic left renal vein joining the left common iliac vein. Eur Radiol 2000;10(11):1724-5.

6. Karaman B, Koplay M, Ozturk E, et al. Retroaortic left renal vein: multidetector computed tomography angiography findings and its clinical importance. Acta Radiol 2007;48(3):355-60.

7. Nguyen BD. Multi-detector CT imaging of double left renal veins. Radiol Case Rep 2006;1(2): 47-49.

8. Matsunaga M, Ushijima T, Fukahori M, Miwa K. A circumaortic left renal vein. BMJ Case Rep 2015;11;2015.

9. Ayaz S, Ayaz ÜY. Detection of retroaortic left renal vein and circumaortic left renal vein by PET/CT images to avoid misdiagnosis and support possible surgical procedures. Hellenic J Nuclear Med 2016;19(2):135-9.

10. Satyapal KS. Infra-renal angles, entry into inferior vena cava and vertebral levels of renal veins. Anat Rec 1999;256(2):202-7. 